\title{
Language Function Used in ELT Textbook Focused on Medical Conversation
}

\author{
I Gusti Ayu Agung Dian Susanthi \\ University of Warmadewa, Bali, Indonesia \\ I Wayan Pastika \\ University of Udayana, Bali, Indonesia \\ Ida Bagus Putra Yadnya \\ University of Udayana, Bali, Indonesia \\ Made Sri Satyawati \\ University of Udayana, Bali, Indonesia
}

\begin{abstract}
The study of language in use has become a crucial issue in every branch of study, such as medical, politics, economics, etc. In doing the interaction for those purposes people use language. The theme of this research is language in use in medical conversation, the data taken from the midwifery conversation of some textbooks of English language teaching for midwifery. This study tries to reveal the language in use in midwifery conversation. On the basis of this research, the question rises as: What kind of language functions used in midwifery conversation? In order to answer this question the theories of language in used proposed by some experts such as Leech (1974), Cook (1994) and Halliday (1985) used as references in this study. However the formulation of language in use redesigned based on the general guidelines in giving the counseling to the patient found in three ELT textbooks mostly used in Indonesian universities especially for midwifery students, this research also presents the occurrence of macro and micro language functions, moreover this research reveals the language in use both in English and Indonesian, thus it helps the teachers in stressing every point of language in use, so that they can easy to teach the expressions and the grammar which can be used in the conversation both in English and Indonesian.
\end{abstract}

Index Terms - language function, language in use, midwifery

\section{INTRODUCTION}

Verbal or nonverbal languages have the same functions, namely as means of communication from the speaker to the listener, so that the idea, meaning and purpose of the speaker can be transferred to the listener. The study of language in use helps the people to know and understand the functions of expression or utterance that can be used in doing the interaction.

In doing the interaction people must have language competence, for Indonesian student improving language competence especially English competence is very important, since it is as foreign language. In learning English for Indonesian student, there are some purposes, namely for general purposes they can study general English, academic purposes they can study English for academic purposes, for example if they want to study in different country, and the third is English for specific purposes or ESP namely studying English for specific profession, such as doctor, midwife, accountant, etc.

This research focuses on the language functions used in midwifery conversation. The language in used itself is categorized into macro and micro. Cook (1994) explained the macro function can be divided into interactive, informative, directive, etc (p.37). While micro function can be classified into 'greeting', 'introducing', 'asking', etc. However based on the conversation in the counseling between midwife and patient, those theory need to redesigned, thus it can be applied in doing the practice. So that the problems are formulated as follows:

a) How is the formulation of language in use for the counseling between midwifery and the patient?

b) What expression can be used based on the formulation?

This paper used the general guideline in formulating the language function used in the counseling between midwifery and patient, the guideline generally ranges from welcoming the patient to the visit conclusion. In details Widaninigsih (2011) described as follows: (1) welcoming the client; (2) Fill the admission form; (3) Asking the pregnancy story; (4) Asking the past pregnancy; (5) Health story; (6) Socio economic; (7) Physical examination; (8) Health education; (9) Labour preparation; (10) Visit conclusion (p.101). By using those guidelines the macro and micro language functions can be formulated, and the expressions can be made, thus this research helps the teachers to stress every point of language in use and they can easy to teach the expressions and grammar both in English and Indonesian. 


\section{Methodology}

The study based on a corpus of three English language teaching textbooks published in Indonesia, those books used generally by the midwifery university students in Indonesia. Those books in detail as follows:

TABLE 1

TEXTBOOKS USED IN THE ANALYSIS

\begin{tabular}{|l|l|l|}
\hline Textbook & Publisher & Year of Publication \\
\hline English for Midwives Practical Guidance for Antenatal Care & Penerbit Buku Kedokteran EGC & 2011 \\
\hline Midwifery English Practical English for Midwifery Student & Pustaka Rihana & 2014 \\
\hline Midwifery English Practical English for Midwifery Student & Rohima Press & 2014 \\
\hline
\end{tabular}

Informal surveys were conducted among university teachers of general English. They were asked whether a particular book was used to teach midwifery conversation at their universities. In Indonesia, some universities have classes especially for English speaking instruction, some may combine speaking and listening. Those three books used in teaching conversation and grammar in Indonesia.

Once the textbooks had been identified and collected, they were examined for information about language in use. The theory proposed by the experts were redesigned based on the finding namely expressions used in the counseling between midwife and the patient. The formulation of language in use is categorized into macro function and micro function. The expressions were categorized based on both of the functions. The expressions are both in English and Indonesian presented in this research.

\section{RESUlTS AND ANALYSIS}

This section presents and discusses the findings in relation to the research questions. We start with the general procedures used in the counseling between midwife and the patient. The textbooks (table 1) shows, there are general procedures used here are the procedures:

(1). Welcome the client

(2) Fill the Admission Form

(3) Asking the Pregnancy Story

(4) Asking the Past Pregnancy

(5) Health Story

(6) Socio Economic

(7) Physical Examination

(8) Health Education

(9) Labour Preparation

(10) Visit conclusion

Based on the collected data the formulation of language functions which designed by the experts cannot be fully applied, thus the formulation are redesigned. Cook (1994) formulated the language function into macro and micro functions. There are two kinds of language functions which similar to the formulation which designed by the experts, namely informative function which is similar to the informational function proposed by Leech (1994), it is used to deliver the information. There are also macro functions which have not been mentioned by the experts, in this research called as interactive interpersonal, which is as an expansion of interpersonal function proposed by Halliday (1973). The next function is called as permissive, it is used by the midwife when examining the patient, and the midwife uses the polite form of sentences in giving command to the patient. Furthermore, communicative function is used in greeting, asking the purpose of the patient. The last is called impressive function, used when the midwife finishes examining the patient, saying thank you in closing the examination can be used as the example for this function. Thus in this article there are six of macro functions used in analyzing language in use in giving service to the patient. The following discussions present those functions in detail.

TABLE 2

LANGUAGE IN USE FOR WELCOMING PATIENT IN ENGLISH AND INDONESIAN

\begin{tabular}{|c|c|c|}
\hline Macro Function & Micro Function & Expressions in English and Indonesian \\
\hline Comunicative & $\begin{array}{l}\text { Greeting (in English) } \\
\text { Menyapa (in Indonesian) }\end{array}$ & $\begin{array}{l}\text { Good morning, how may I help you? } \\
\text { Selmat pagi, ada yang bisa saya bantu? (Indonesian) } \\
\text { (Widaningsih, 2011) }\end{array}$ \\
\hline Permissive & $\begin{array}{l}\text { Giving an order (in English) } \\
\text { Menyuruh (in Indonesian) }\end{array}$ & $\begin{array}{l}\text { Please would you like to sit down? } \\
\text { Silahkan duduk (Indonesian) } \\
\text { (Widaningsih, 2011) }\end{array}$ \\
\hline Informative & $\begin{array}{l}\text { Asking for information (in English) } \\
\text { Menanyakan (in Indonesian) } \\
\text { Confirming (in English) } \\
\text { Memastikan } \\
\text { (in Indonesian) }\end{array}$ & $\begin{array}{l}\text { Is this your first time for you to come here? } \\
\text { Apakah ini pertama kalinya anda datang kemari? } \\
\text { If it is so. I will fill in your card first } \\
\text { Apabila iya. saya akan mengisi registrasi } \\
\text { (Widaningsih, 2011) }\end{array}$ \\
\hline
\end{tabular}


Based on table (2) above, the macro functions used in welcoming the patient are communicative, directive and informative. While the micro functions are greeting, ordering, asking information and confirming. Occasionally, some textbooks used in this study offer information by arranging linguistic expressions how to say greeting according to degree of formality, as illustrated in Extract I below:

EXTRACT I.

ADAPTED FROM MIDWIFERY ENGLISH PRACTICAL ENGLISH FOR MIDWIFERY STUDENT

\begin{tabular}{|c|c|}
\hline \multirow{4}{*}{$\begin{array}{l}\text { Formal } \\
\text { Informal }\end{array}$} & Greetings \\
\hline & $\begin{array}{l}\text { Good Morning, how may I help you? (English) } \\
\text { Selamat pagi, ada yang bisa saya bantu? (Indonesian) }\end{array}$ \\
\hline & $\begin{array}{l}\text { Hello, Mrs Anita. How are you? (English) } \\
\text { Hallo, Nyonya Anita. Apa kabar? (Indonesian) }\end{array}$ \\
\hline & $\begin{array}{l}\text { Hi, how are you doing? (English) } \\
\text { Hai, bagaimana kabar? (Indonesian) }\end{array}$ \\
\hline
\end{tabular}

According to Brown and Levinson (1987), the difference in using formal and informal expressions is affected by social stautus, social distance. However, most students do not know the reason in using those expressions. So that the teacher must explain the factors influencing the formality of various expressions, thus the student can posit themselves on the right position. In English we can greet people formally by saying "good morning", "good afternoon" or "good evening", while "hello" or "hi" can be less formal. So that in Indonesian we can greet people formally by saying "selamat pagi" in the morning, "selamat siang" in the afternoon" and "selamat malam" in the evening, while "hallo" or hai can be less formal. In Indonesian "hallo" or "hai" can be used when we greet friends.

TABLE 3

LANGUAGE IN USE IN FILLING THE ADMISSION FORM

\begin{tabular}{|l|l|l|}
\hline \multicolumn{2}{|c|}{ Macro Function } & \multicolumn{1}{|c|}{ Micro Function } \\
\hline Permissive & $\begin{array}{l}\text { Asking (in English) } \\
\text { Meminta (in Indonesian) }\end{array}$ & $\begin{array}{l}\text { May I have your ID card? } \\
\text { Bolehkah saya meminta kartu identitas } \\
\text { anda? (Widaningsih, 2011) }\end{array}$ \\
\hline Informative & $\begin{array}{l}\text { Confirming (in English) } \\
\text { Memastikan (in Indonesian) }\end{array}$ & $\begin{array}{l}\text { According to your ID card, your name is } \\
\text { Thalia, right? } \\
\text { Menurut kartu identitas anda, nama anda } \\
\text { Thalia, bukan? (Widaningsih, 2011) }\end{array}$ \\
\hline Impressive & $\begin{array}{l}\text { Thank you } \\
\text { Terimakasih (Widaningsih, 2011) }\end{array}$ \\
\hline
\end{tabular}

Based on table (3) above, the macro functions used in welcoming the patient are permissive, informative, and impressive. While the micro functions are asking, confirming, and saying thanks. In asking the ID card of the patient both the English and Indonesian expressions are in polite form. The midwife tend to use "May I have?" or "Bolehkah saya?", rather than direct command such as "give me your ID card!" or "serahkan kartu identitas anda!". In forming a polite sentence for asking something in Indonesian may use boleh + kah (bound morpheme) + saya (subject) or in English can be may (modal) $+I$ (subject). In Indonesian, it has the similar way in confirming the information the tag question can also be used, for example "menurut kartu identitas anda, nama anda Thalia, bukan?" the word "bukan" aims at confirming information.

TABLE 4

LANGUAGE IN USE IN ASKING THE PREGNANCY STORY

\begin{tabular}{|l|l|l|}
\hline Macro Function & Micro Function & Expression in English and Indonesian \\
\hline Informative & $\begin{array}{l}\text { Asking for Information } \\
\text { (in English) } \\
\text { Menanyakan } \\
\text { (in Indonesian) }\end{array}$ & $\begin{array}{l}\text {-When did you feel the first fetal movement? } \\
\text { Kapankah pertama kalinya anda merasakan } \\
\text { pergerakan pada janin anda?" } \\
\text { (Widaningsih, 2011) }\end{array}$ \\
\hline Interactive interpersonal & $\begin{array}{l}\text { Giving suggestion } \\
\text { (in English) } \\
\text { Menyarankan } \\
\text { (in Indonesian) }\end{array}$ & $\begin{array}{l}\text { Good, to avoid nausea, before you get up from bed, it } \\
\text { will be better you take sweet warm tea and a biscuit } \\
\text { Bagus, untuk menghindari mual sebelum anda } \\
\text { bangun dari tempat tidur, sebaiknya anda minum teh } \\
\text { hangat dan biscuit } \\
\text { (Widaningsih, 2011) }\end{array}$ \\
\hline
\end{tabular}

Based on table (4) above, the macro functions used in ELT textbooks for asking the pregnancy story are informative, and interactive interpersonal. While the micro functions are asking for information, and giving suggestion. In giving suggestion in English, we can say it will be better, so it is in Indonesian we can say sebaiknya or ada baiknya. 
TABLE 5

LANGUAGE IN USE FOR ASKING THE PAST PREGNANCY

\begin{tabular}{|l|l|l|}
\hline Macro Function & Micro Function & Expression in English and Indonesian \\
\hline Informative & $\begin{array}{l}\text { Asking for information } \\
\text { (in English) }\end{array}$ & -In your last pregnancy, did you feel nausea, vomiting and may be bleeding? \\
& Menanyakan & Pada kehamilan sebelumnya, apakah anda merasakan mual, muntah atau perdarahan? \\
& how about your last delivery, was it spontaneously or did you need caesarean section? \\
& $\begin{array}{l}\text { Asking for information } \\
\text { (in English) }\end{array}$ & Bagaimanakah persalinan anda pada kehamilan sebelumnya, apakah spontan atau \\
& Caesar? \\
& (Widaningsih, 2011) \\
& & \\
\hline
\end{tabular}

Table (5) above shows, the macro function used in the ELT textbooks for asking the pregnancy story is informative. While the micro functions is asking for information. In asking for information about the past pregnancy, we can use did you feel....? How about....? Or in Indonesian can be apakah anda merasa...? Bagaimanakah dengan...? So In Indonesian question word apa $+k a h$ (bound morpheme)+ anda (object) + merasa (verb).

TABLE 6

LANGUAGE IN USE IN ASKING HEALTH HISTORY

\begin{tabular}{|l|l|l|}
\hline Macro Function & Micro Function & Expression in English and Indonesian \\
\hline Informative & $\begin{array}{l}\text { Asking for information } \\
\text { (in English) } \\
\text { Menanyakan } \\
\text { (in Indonesian) }\end{array}$ & $\begin{array}{l}\text {-have you ever been seriously ill? } \\
\text { Apakah anda pernah sakit yang serius? } \\
\text {-is there any problem about passing urine or } \\
\text { defecation? } \\
\text { Apakah anda mengalami masalah pada saat buang air } \\
\text { kecil dan buang air besar } \\
\text { (Widaningsih, 2011) }\end{array}$ \\
\hline Interactive interpersonal & $\begin{array}{l}\text { Relaxing (in English) } \\
\text { Menenangkan } \\
\text { (in Indonesian) }\end{array}$ & $\begin{array}{l}\text { Passing urine is often caused by the pressure of } \\
\text { baby's head to the bladder. But it is a physiological } \\
\text { effect. So you need not to worry about it, just take it } \\
\text { easy or relax } \\
\text { Buang air kecil disebabkan oleh tekanan dari kepala } \\
\text { bayi ke kandung kemih. Akan tetapi, hal tersebut } \\
\text { adalah efek psikologis. Jadi, anda tidak usah khawatir } \\
\text { tentang itu, tenanglah } \\
\text { (Widaningsih, 2011) }\end{array}$ \\
& $\begin{array}{l}\text { Thank you for your explanation } \\
\text { Terimakasih atas penjelasannya } \\
\text { (Widaningsih, 2011) }\end{array}$ \\
\hline Impressive & $\begin{array}{l}\text { Saying thanks (in English) } \\
\text { Berterima kasih (in Indonesian) }\end{array}$ & \\
\hline
\end{tabular}

Table (6) above shows, the macro functions used in the ELT textbooks in asking health story are informative, interactive interpersonal and impressive. While the micro functions are asking for information, relaxing and saying thanks. It is important to make the patient relax during the pregnancy period, in this case the midwife can give explanation and say don't worry or in Indonesian cab be jangan khawatir. or tenanglah. It is very important to make the patient relax in order to avoid their stress during the pregnancy.

TABLE 7

LANGUAGE IN USE IN ASKING SOCIO ECONOMIC

\begin{tabular}{|c|c|c|}
\hline Macro Function & Micro Function & Expression in English and Indonesian \\
\hline Informative & $\begin{array}{l}\text { Asking for Information } \\
\text { (in English) } \\
\text { Menanyakan } \\
\text { (in Indonesian) } \\
\text { Asking for Information } \\
\text { (in English) } \\
\text { Menanyakan } \\
\text { (in Indonesian) }\end{array}$ & $\begin{array}{l}\text {-during this pregnancy, what kind of } \\
\text { food do you take for meal? } \\
\text { Selama kehamilan ini makanan apa saja } \\
\text { yang anda konsumsi? } \\
\text { What are your activities at home? } \\
\text { Apa saja kegiatan anda di rumah? } \\
\text { (Widaningsih, 2011) }\end{array}$ \\
\hline Interactive interpersonal & $\begin{array}{l}\text { Giving Suggestion } \\
\text { (in English) } \\
\text { Menyarankan } \\
\text { (in Indonesian) }\end{array}$ & $\begin{array}{l}\text {-Potato/cereal, animal protein, vegetable } \\
\text { protein, vegetables and fruit. It is very } \\
\text { good and it will be better when you add } \\
\text { some milk. } \\
\text { Kentang/sereal, protein hewani, protein } \\
\text { nabati, sayuran dan buah. Makanan } \\
\text { tersebut sangatlah baik dan akan sangat } \\
\text { baik apabila ditambahkan dengan susu } \\
\text { (Widaningsih, 2011) }\end{array}$ \\
\hline
\end{tabular}

Based on table (7) above, the macro functions used in asking the socio economic are informative, and interactive interpersonal. While the micro functions are asking for information, and giving suggestion. Another expressions in 
giving suggestion in Indonesian are sangatlah baik mengkonsumsi (it is very good to consume...) or akan sangat baik mengkonsumsi (it will be better to consume...) in English it is said it will be better as it is shown on table (7).

TABLE 8

LANGUAGE IN USE IN PHYSICAL EXAMINATION

\begin{tabular}{|c|c|c|}
\hline Macro Function & Micro Function & Expression in English and Indonesian \\
\hline Informative & $\begin{array}{l}\text { Asking for information } \\
\text { (in English) } \\
\text { Menanyakan } \\
\text { (in Indonesian) }\end{array}$ & $\begin{array}{l}\text { Is your hair thinning? } \\
\text { Apakah rambut anda menipis? } \\
\text { (Widaningsih, 2011) }\end{array}$ \\
\hline Permissive & $\begin{array}{l}\text { Giving an order } \\
\text { (in English) } \\
\text { Menyuruh } \\
\text { (in Indonesian) }\end{array}$ & $\begin{array}{l}\text { Now I'd like to check your eyes condition conjunctive and sclera. } \\
\text { Excuse me, look up, look down. Thank you. } \\
\text { Sekarang saya akan memeriksa kondisi mata anda konjungtiva dan } \\
\text { sclera. Permisi lihat ke atas, lihat ke bawah. Terima kasih. } \\
\text { (Widaningsih, 2011) }\end{array}$ \\
\hline Impressive & $\begin{array}{l}\text { Saying thanks } \\
\text { (in English) } \\
\text { Berterima kasih } \\
\text { (in Indonesian) } \\
\end{array}$ & $\begin{array}{l}\text { Thank you } \\
\text { Terimakasih } \\
\text { (Widaningsih, 2011) }\end{array}$ \\
\hline Interactive interpersonal & $\begin{array}{l}\text { Giving Suggestion } \\
\text { (in English) } \\
\text { Menyarankan } \\
\text { (in Indonesian) }\end{array}$ & $\begin{array}{l}\text { You should not take a bath with cool water or drink cool water } \\
\text { and eat cool foods that come out from refrigerator } \\
\text { Sebaiknya anda mandi tidak dengan air dingin ataupun minum air } \\
\text { dingin dan makan makanan yang dingin yang baru saja } \\
\text { dikeluarkan dari lemari es } \\
\text { (Widaningsih, 2011) }\end{array}$ \\
\hline
\end{tabular}

Based on table (8) above, the macro functions used in physical examination are informative, permissive, impressive and interactive interpersonal. While the micro functions are asking for information, ordering, saying thanks and giving suggestion. In giving a direct order, the midwife can make the sentence more polite by saying excuse me, or can you.....? or in Indonesian it can be permisi.... or bisakah anda....? rather than direct command such as "lie down on the bed now!" or in Indonesian "berbaring sekarang!". The midwife can choose the polite form to make the patient relax and comfortable during the examination.

TABLE 9

LANGUAGE IN USE IN GIVING HEALTH EDUCATION

\begin{tabular}{|l|l|l|}
\hline Macro Function & Micro Function & Expression in English and Indonesian \\
\hline Informative & $\begin{array}{l}\text { Asking for Information } \\
\text { (in Englsih) } \\
\text { Menanyakan } \\
\text { (in Indonesian) }\end{array}$ & $\begin{array}{l}\text { Could you tell me how many times do you take a bath? } \\
\text { Bolehkah saya tahu berapa kalikah anda mandi dalam sehari? } \\
\text { (Widaningsih, 2011) }\end{array}$ \\
\hline Interactive interpersonal & $\begin{array}{l}\text { Giving Suggestion } \\
\text { (in English) } \\
\text { Menyarankan } \\
\text { (in Indonesian) }\end{array}$ & $\begin{array}{l}\text { During pregnancy, usually you get perspiration or sweat so it } \\
\text { will be better for you if you take a bath more than once } \\
\text { Selama kehamilan, tentunya anda lebih banyak berkeringat, akan } \\
\text { lebih baik apabila anda mandi lebih dari satu kali dalam sehari } \\
\text { (Widaningsih, 2011) }\end{array}$ \\
\hline
\end{tabular}

Based on table (9) above, the macro functions used in asking giving health education are informative, and interactive interpersonal. While the micro functions are asking for information, and giving suggestion. In giving suggestion it can be it will be better for you if you... or in Indonesian akan lebih baik apabila.....In asking for information the polite form can be used such as could you tell me how....? Or in Indonesian bolehkah saya tahu....? In this case avoid of using direct command such as "tell me how many times you take a bath" or in Indonesian "beritahukan kepada saya berapa kali anda mandi”.

TABLE 10

LANGUAGE IN USE IN ASKING LABOUR PREPARATION

\begin{tabular}{|l|l|l|}
\hline Macro Function & Micro Function & Expression in English and Indonesian \\
\hline Informative & Asking for Information & What is your preparation for your delivery? \\
& (in English) & Persiapan apakah yang anda lakukan untuk \\
& $\begin{array}{l}\text { Menanyakan } \\
\text { (in Indonesian) }\end{array}$ & persalinan anda? \\
(Widaningsih, 2011)
\end{tabular}

Based on table (10) above, the macro functions used in asking the pregnancy story are informative, and interactive interpersonal. While the micro functions are asking for information, and giving suggestion. In asking preparation for delivery, the midwife can use what is your preparation....? Or in Indonesian persiapan apakah...? Rather than giving direct command you must go to.....! 
TABLE 11

LANGUAGE IN USE IN GIVING VISIT CONCLUSION

\begin{tabular}{|l|l|l|}
\hline Macro Function & Micro Function & Expression in English and Indonesian \\
\hline Interactive interpersonal & $\begin{array}{l}\text { Giving Suggestion } \\
\text { (in Englsih) } \\
\text { Menyarankan } \\
\text { (in Indonesian) }\end{array}$ & $\begin{array}{l}\text { It will be better if you check your pregnancy regularly, and } \\
\text { the next coming is on the } 5^{\text {th }} \text { of August } \\
\text { Lebih baik anda memeriksa kehamilan anda secara teratur, } \\
\text { dan pemerkisaan selanjutnya adalah tanggal 5 Agustus } \\
\text { (Widaningsih, 2011) }\end{array}$ \\
\hline
\end{tabular}

Based on table (11) above, the macro functions used in asking the pregnancy story are informative, and interactive interpersonal. While the micro functions are asking for information, and giving suggestion. In giving visit conclusion the point is giving suggestion, thus the expression it will be better....or in Indonesian lebih baik.....can be stressed by the teacher in teaching this point.

The occurrence of macro and micro functions can be seen on the tables as in below:

TABLE 12

THE OCCURRENCE OF MACRO FUNCTIONS

\begin{tabular}{|l|c|}
\hline \multicolumn{1}{|c|}{ Macro Functions } & $\begin{array}{c}\text { The Occurrence of } \\
\text { Macro Functions } \\
\text { (Times) }\end{array}$ \\
\hline Communicative & 1 \\
\hline Informative & 9 \\
\hline Impressive & 3 \\
\hline Interactive Interpersonal & 6 \\
\hline Permissive & 3 \\
\hline
\end{tabular}

TABLE 13

THE OCCURRENCE OF MICRO FUNCTIONS

\begin{tabular}{|l|c|}
\hline Micro Function & $\begin{array}{c}\text { The Occurrence of Micro Functions } \\
\text { (Times) }\end{array}$ \\
\hline Greeting & 1 \\
\hline Giving an order & 2 \\
\hline Asking for information & 8 \\
\hline Confirming & 2 \\
\hline Asking & 1 \\
\hline Saying Thanks & 2 \\
\hline Giving Suggestion & 5 \\
\hline Relaxing & 1 \\
\hline
\end{tabular}

The occurrence of macro and micro functions can give contribution to the teachers and textbooks writers. The occurrence can help the teacher to reduce the gap between the student need and what the ELT textbooks offer for the learners. Teachers should be aware of this condition and by seeing and understanding the macro and micro in using the language, the teacher can find out the effective ways to raise the students' competence in using the expressions, formality, social status, social distance, and politeness. Moreover, teacher can see what function that mostly used in the counseling between midwife and patient, it is shown (table 13) asking information and giving suggestion to the patient has the high frequency in the counseling, teacher can give explanation about the grammar, the polite form that can be used in asking information and giving suggestion more intensively, the polite form is important to be suggested to the students, in order to make the patient feel relax and comfortable during the counseling. However, much time and effort are needed for teacher to find more information on linguistics midwifery study. The busy live of ELT teachers will make this condition not always be possible, especially in Indonesia where the teacher have busy schedules and large classes. Therefore, it is important for the textbooks writers to offer well-designed textbooks that present more examples of expressions such as in the real practice.

\section{DisCUSSION AND CONCLUSION}

ELT textbooks often present expressions without explanation about the functions. Even if there is no illustration for student when some expressions and what for the expressions are used. This research has tried to reveal the benefit of introducing language in use in the field of medical linguistics. The formulations of language in use in the conversation between midwife and patient help the teacher to determine and develop the material in teaching speaking especially conversation for the midwifery student both in English and in Indonesian. The occurrence of micro functions (see table 13) will be very beneficial in studying the English for midwife, in this case the teacher can give the material in terms of how to greet the patient, how to give command( in polite form), how to ask information, how to confirm, how to ask patient to do something, how to say thanks, how to give suggestion and how to make the patient relax during the counseling, the teacher can give some choices of sentences, explain the grammar and so on. Without knowing the language functions, the teacher will face difficulties to select the appropriate dialog which contain different functions, since the dialog on the textbooks does not focus on the need of the student speaking activity. ELT textbooks provide some outcomes, however in doing the speaking practice for student the material has to be expanded. In addition, it has been acknowledged that there is lack of research exploring difficulties of language in used which focused on medical study especially midwifery. So that, future language functions research is needed to enrich the language functions knowledge especially on medical subject.

\section{REFERENCES}

[1] Brown, P and S.C. Levinson. (1987). Politeness: Some Universals in Language Usage. Cambridge: Cambridge University Press. [2] Cook, G. (1994). Discourse and Literature. Oxford: Oxford University Press. 
[3] Halliday, MAK. Dan Hassan, Ruqaiyah. (1985). Language, context, and text: Aspect of language in a social semiotic perspective. Victoria: Deakin University Press.

[4] Halliday, MAK. (1973). Explorations in the Function of Language. London: Edward Arnold.

[5] Haryani, S. (2014). Midwifery English Practical English for Midwifery Student. Yogyakarta: Pustaka Rihama.

[6] Haryani, S. (2014). Midwifery Englsih Practical English for Midwifery Student. Yogyakarta: Rohima Press.

[7] Holmes, J .( 2001). An Introduction to Sociolinguistics. England: Longman.

[8] Hymes, D. (1962). The Etnography of Speaking. Washington DC: Anthropology Society of Washington.

[9] Hymes, D. (1974). Foundation of Sociolinguistics: An Etnography Approach. Philadelphia: University of Pennsylvania Press.

[10] Jacobson, R. (1960). Closing Statement: Linguistics and Poetics. Cambridge: MIT Press.

[11] Leech, G. (1974). Semantics. England: Penguin Book.

[12] Medforth, J. (2006). Oxford Handbook of Midwifery. Oxford University Press: New York.

[13] Medforth, J. (2010). Buku Kebidanan Oxford. Jakarta: Penerbit Buku Kedokteran EGC.

[14] Widaningsih, I. (2011). English for Midwives Practical Guidance for Antenatal Care. Jakarta: Penerbit Buku Kedokteran EGC.

[15] Winson, N \& McDonald, S. (2005). Kamus Kebidanan Bergambar. Jakarta: Penerbit Buku Kedokteran EGC.

I Gusti Ayu Agung Dian Susanthi works in Warmadewa University Denpasar Bali and taking doctoral program in Udayana University, she is currently a lecturer in Warmadewa University and teaching linguistics in some medical universities in Bali Indonesia. Her interests include linguistics and translation studies, and she is also free translator in her free time.

I Wayan Pastika is a professor in Udayana University Denpasar Bali, he is also a lecturer and an expert in the field of research methodology of linguistics study who gave contribution in doing this research. He is currently as an invited Professor teaching linguistics in Osaka University, Japan.

Ida Bagus Putra Yadnya is also a professor in Udayana University Denpasar Bali, he is an expert in translation study, and he also gave significant contribution in analyzing the data in this research. Professor Putra Yadnya took part in several national and international seminar and conferences in some universities in Indonesia in the field of linguistics study.

Made Sri Satyawati is an expert in linguistics study as well as typology who gave a lot of contribution in analyzing the text analysis. She is also a lecturer and a secretary of Linguistics Program for Doctorate Degree in Udayana University Denpasar Bali. 